\title{
Loys Dorléans and the "Catholiques Anglois": A Common Catholic History between Violence, Martyrdom and Human and Cultural Networks
}

\author{
Marco Penzi \\ IHMC Université Paris1. 51rue Basfroi 75011 Paris \\ e-mail: mp295@hotmail.fr \\ ORCID iD: http://orcid.org/0000-0002-5414-0186
}

Submitted: 16 October 2016. Accepted: 28 February 2017

\begin{abstract}
In 1586 the book Advertissement des Catholiques Anglois aux François catholiques, du danger où ils sont de perdre leur religion was edited in Paris: the author, the Ligueur Loys Dorléans wanted to show what would be the future of France under the dominion of an heretical king, using as example the sufferings of the contemporaries English Catholics. The book knew many editions and Dorléans published other works on the same subject. In 1592 the Catholique Anglois, was printed twice in Spanish, in Madrid and Zaragoza. The history of the edition of Dorléans' texts in Spanish must be understood as an effort of the English Catholic refugees and their network of alliances in Spain to demonstrate their tragic situation to the public. The Spanish editions of Dorléans' work were made at the same time when new English Colleges were opened in the Spanish Kingdom.
\end{abstract}

KEYWORDS: $16^{\text {th }}$ Century; Wars of Religion; Printing; Spain; France; English Catholics; Propaganda.

Citation / Cómo citar este artículo: Penzi, Marco (2017) "Loys Dorléans and the "Catholiques Anglois": A Common Catholic History Between Violence, Martyrdom and Human and Cultural Networks". Culture \& History Digital Journal, 6 (1): e004. doi: http://dx.doi.org/10.3989/chdj.2017.004.

RESUMEN: Loys Dorléans y los "Catholiques Anglois": una historia católica común entre la violencia, martirio y redes humanas y culturales.- En 1586 se editaba en París el libro Advertissement des Catholiques Anglois aux François catholiques, du danger où ils sont de perdre leur religion. Su autor, el miembro de la liga católica francesa Loys Dorléans quería advertir de cómo sería el futuro de Francia bajo el dominio de un rey hereje, tomando para ello como ejemplo el sufrimiento que por entonces padecían los Católicos ingleses. El libro fue reeditado en varias ocasiones y Dorléans publicó otras obras sobre el mismo tema. En 1592, el Catholique Anglois fue objeto de dos ediciones hispanas, una en Madrid y otra en Zaragoza. La historia de las publicaciones en versión hispana del texto de Dorléans han de ser entendidas como parte del esfuerzo realizado por los refugiados católicos ingleses y sus redes de aliados en la Monarquía Hispánica con el fin de dar a conocer su trágica publicación al público. Las ediciones hispanas de Dorléans fueron también simultáneas a la apertura de colegios ingleses en la Monarquía Hispánica.

PALABRAS CLAVE: Siglo XVI; Guerras de Religión, Imprenta; Monarquía Hispánica; Francia; Católicos Ingleses; Propaganda.

Copyright: (C) 2017 CSIC. This is an open-access article distributed under the terms of the Creative Commons Attribution License (CC BY) Spain 3.0. 
In 1586 Loys Dorléans, avocat of the Parlement of Paris, published his book with the title Advertissement des Catholiques Anglois aux François catholiques, du danger où ils sont de perdre leur religion (Dorléans, 1586). The leaguer author wanted to show what would be the future of France under the dominion of a heretical king, using as example the sufferings of contemporary English Catholics. The Parisian Loys Dorléans (15421629) avocat at the parliament of Paris, was a poet, with published poetical works (1572 and others posthumously in 1631) (Dorléans, 1572; Dorléans 1631), a committed pamphleteer, a member of the French Catholic League, one of its Parisian founders, and of the Seize (Descimon, 1983:133-134). He studied under Jean Dorat and later started a legal career. He was named avocat général au Parlement de Paris on Saturday, $21^{\text {st }}$ January 1589 after the taking over of the Sainte Union of the institution. He was known for being one of the most prolific and engaged authors of the League, till the assassination of Brisson Larcher and Tardif in November 1591 (Barnavi and Descimon, 1985). After this tragic event he asked for the punishment of the ones found guilty. At the return of the duke of Mayenne in Paris, and the execution of some of the conspirators, he somehow left the Seize, but remained still a Catholique Zélé (leaguer). He was committed to the party of the duke, but his detachment from the core group and ways of the Seize seems to be effective when on $30^{\text {th }}$ October 1592, he pronounced an harangue at the Parlement in which he defined the Seize as "gens de néant, et cependant si outrecuidés et impudents, qu'ils s'étaient voulu depuis un peu mêler et disposer de l'Etat et couronne, et la mettre sur la tête d'un Espagnol, comme s'il n'y eût point eu d'assez puissants et braves princes en France pour la porter: en quoi ils faisaient tort à tous les princes, et particulièrement au duc de Mayenne là présent, et à tous ceux de sa maison." In the same way, he raised his voice against the Parisian preachers saying that "qu'il était besoin de réfréner leurs langues, qui déchiraient les princes et se mêlaient des affaires d'Etat, où ils n'entendaient du tout rien. De quoi les prédicateurs avertis furent incontinent trouver le duc de Mayenne, pour le prier de chasser ledit Dorléans comme un mutin qui s'était bandé contre l'Eglise de Dieu et ses ministres" (de L'Estoile, 1948: 189).

This latter speech caused troubles with the Parisians curés and Mayenne sided with Dorléans, ordering to the city clergy not to meddle in the Politics of the State. This action of the Duke signed the division and increased the mistrust of the Parisian Sixteen and preachers against Mayenne. According to the memoirist L'Estoile, Dorléans changed his mind the following Tuesday, $22^{\text {nd }}$ December, when he harangued the Parliament for war, insulting Henri de Navarre, and calling the magistrates of the Parlement of Châlons heretical and schismatic: 200 silver écus he had supposedly received from the Spanish envois could have facilitated this (de L'Estoile, 1948: 203).

On $22^{\text {nd }}$ March 1594, he left Paris with the Spanish garrison, and took refuge in the Spanish Low Countries, living in Antwerp till 1603, when he returned to France under the protection and sauf-conduit of some letters of the chancellor Pomponne de Bellièvre. Back in Paris, some time later, Dorléans was detained at the Conciergerie, under the pretext, as it seems, that he forgot to greet the President of this institution upon his return as lawyer. Most probably he was jailed either for debts he left unpaid since the time of the League or for the fact he sided with the League when the Parliament was ousted in January 1589 . He was later graced by Henri IV (Poncet, 1998: 210-211). After these events, as Dorléans himself wrote in his Remerciement au Roy, now 64 years old, he became a loyal follower of the king of France (Dorléans 1604, $1612)^{1}$. He resumed his career as lawyer, poet, and writer: in his later years he published in 1607 Les Ouvertures de Parlemens (1607; analysed by Fumaroli, 1994: 427-429), and in 1622 a commentary of Tacitus (Dorléans, 1622). He died in 1629.

When Dorléans edited his Advertissement des Catholiques Anglois in 1586, the danger of an heretic to become the new king of France, was very present: since François duc d'Anjou, the last brother of the childless king Henri III died on $10^{\text {th }}$ June 1584 , the presumptive heir to the crown of the French kingdom was Henri, King of Navarre, Protestant, and head of the Huguenots' party. In 1585 Navarre and his also Protestant cousin Henri de Bourbon, who was coming next in line for the succession to the French throne, were both excommunicated by the Pope Sixtus V.

Already at the end of 1584 , a family pact involving the Guise (the duke Henri, and his brothers Mayenne and the Cardinal Louis, the duke of Lorraine, and their cousin, the duke of Mercoeur), and Antoine Cardinal of Bourbon was concluded with the aim to keep Navarre off the throne. They also gained the support of Philip II, King of Spain, who authorized his agents to sign the Treaty of Joinville (31 ${ }^{\text {st }}$ December 1584$)$, with Guise. The allies undertook to defend the Catholic faith in France, and to fight Protestantism in France as well as in the Low Countries. Further, they recognized Antoine Cardinal of Bourbon, the uncle of Navarre and Condé, as the rightful heir, according to the Salic law, but also the Loi de Catholicité, that had been adopted during the Estates General of 1576. The pact stipulated also that the decrees of the Council of Trent had to be registered by the Parlament in France; that the future king was to renounce to the alliance with the Turks and to stop French privateering. On his side, the king of Spain promised important monthly subsidies.

Later that year, on $31^{\text {st }}$ March 1585 , the League published a manifesto in Péronne that explained the reasons that had led the Cardinal de Bourbon, the princes, peers, lords, cities and communities, to oppose those who wanted to subvert the Catholic Religion of the Realm. The manifesto urged the Catholics to prepare for a new civil war, the King to renounce his "mignons" and to place valuable and truly Catholic administrators at his side; the manifesto also called for the abolition of some taxes and extraordinary subsidies introduced since the reign of Charles IX (Bourbon, 1585). The King and the League came to a common understanding by signing a treaty in 
Némours on $7^{\text {th }}$ July 1585 (Penzi, 2015). Meanwhile the League had gained support in the towns and cities of France and in particular in Paris, which was one of the most radical.

Despite the signed treaties and his promises, it soon became clear that Henri III had no serious intention of fighting the Huguenots. He also left the conduct of state affairs to his mother Catherine de Medici. The League, on the contrary, went to war: Mercoeur defeated Condé in Brittany and Anjou, as well as Mayenne, fought Turenne in Périgord and Saintonge. During the winter of 1586, Navarre tried to win time negotiating with the Queen Mother, while his agents were raising troops and money in Germany. It was at this time of the struggle for the "survival of the Catholic Religion", that Dorléans published his book. Loys Dorléans entered the polemical arena of the diatribe concerning the succession to the kingdom against the Protestant writers who were defending Navarre's rights. The "Catholique anglois" was a French polemic that used the image of the Catholics and the martyrs of England to show the French what their fate would be under a heretic king. At the same time, maybe even without Dorléans knowledge, the book was opening the polemic to all of Catholic Europe. Adopting the guise of an English Catholic, Dorléans urged the French to join the Catholic League, to defend the religion, and to save themselves from an awful fate such as the one the English had befallen. Dorléans gave accounts of the terrible tortures Jezabel of England had inflicted upon the innocent Catholics; the book urged the French to adopt remedies for a situation that still was not so dramatic as that of England, to adopt moral reform as well as to prevent any further action of the Huguenots, and, finally, to go to war against them (L'Estoile1875, vol. 2: 392-393). ${ }^{2}$

The work was an editorial success and underwent different reworked reeditions (Dorléans, 1587a; Dorléans 1590); while provoking a number of replies. Amongst them Duplessis-Mornay published in 1587 a Lettre d'un gentilhomme Catholique (Duplessis-Mornay, 1587), in which he tried to point out Dorléans' credulity, his factual errors and the lies expressed in his work. To all his critics Dorléans answered in 1587 with his Replique pour le Catholique anglois (Dorléans, 1587b), a simple reiteration of his former arguments, and an effort to refute his adversaries' pamphlets. ${ }^{3}$

There's no direct evidence that Dorléans had any personal ties with the English Catholics refugees in Paris; nethertheless it could be possible that the Frenchman had been knowing and helping some English or Scottish Catholics in the capital of France (Gibbons, 2011: 106; Gould, 1975: 17). It is clear, that he was sympathizing with their situation, and their misfortunes. In his pamphlet Dorléans makes some direct references to the exiled in Paris and the help they had received (Dorléans, 1586: 89): ${ }^{4}$ clearly, he remembers the fate of Thomas Morgan (Dorléans, 1586:16). ${ }^{5}$

In 1587 , in Paris at the cemetery of the Saint Innocents some etchings representing the fate of the English Catholics under Elizabeth I had been exposed, attracting a very large audience. These etchings were made by or taken from the work of Richard Verstagen, an English Catholic who published his Théâtre des cruautés in Paris the same year (Lestringant, 1995) and in Latin in Antwerp (Arblaster, 2004): the author, who had escaped from England, had found shelter in Rome and then gone to Paris, under the protection of the papal nuncio. In Paris, like many other English or Scottish Catholics, he committed himself to the clan of the Guise, who offered protection and support in the city, but also to the English College that was at that time in Reims. The Guise were cousins to the Queen of Scotland, Mary Stuart, who at that point in time Elizabeth held prisoner and later ordered beheaded.

When in 1591-1592 the book went out of print in France, due to the political French context of those years, the Catholique Anglois, was surprisingly reprinted twice in a Spanish version, in Madrid (Dorléans, 1592a) and Zaragoza (1592b). In those years, after the disaster of the Spanish Armada of 1588, Spain was still at war against England, and remained, together with Rome, the major financial supporter of the English, Scottish and Irish Catholic refugees on the continent, particularly in Iberia, and in the Spanish Low Countries, not to mention the Farnese campaigns to help the French Catholic League, one in 1590 and the second and last one for Parma to happen in the summer of 1592. The Spanish edition of the work of Dorléans was made in association with other texts concerning the 1590 siege of Paris, and further events of the end of the Wars of Religion.

The question that arises is the following: why was Dorléans suddenly translated into Spanish, six years after his text appeared in France, and four years after the Armada? In addition, why was it published twice in such a very short time span, in two almost identical editions?

Interest in English Catholics in Spain seemed to continue after the Armada's unlucky expedition: various works were edited in Spanish concerning the religious and political situation in England (Pedro Rivadeneira, por Pedro Madrigal, 1588, 2 editions; ${ }^{6}$ Herrera, 1589; Persons, 1590; Anonymous, 1592b). Nor had interest in the "sucesos de Francia" faded away: the public interest in the events happening in France and the Low Countries is reflected not only in publications on the subject, but also by the attention Spanish historians paid to the expeditions of Farnese's tercios to rescue Paris, or to Philip II's fight to save the Catholic Religion in France (Grê Ponce, 2014: 463-475). For example, Rutger Velpius editor in Brussels who was printing books in French concerning contemporary historical events in France, was also publishing texts in Spanish aimed to be sold on the Iberian market: amongst these books between the crónicas on the history of France printed in his shop we found in particular two, both works of Pedro Cornejo (Cornejo, 1591a; Cornejo, 1591b; see Pallier, 1975, N708: 382-383; Rodriguez Perez, 2003: 51-56; Manrique Figueroa, 2012: 211-212). ${ }^{7}$ In 1592 Cornejo's Compendio y breve relación de la Liga, was edited in Madrid by Pedro Madrigal (Cornejo 1592; see Penzi, 2003). ${ }^{8}$ Thus, it is not surprising that, 
due to what seems to be a general European demand for news about events in France the Low Countries, the most important polemical pamphlet of Loys Dorléans was also published in Spain. However, it still remains surprising that two editions were printed in the same year, 1592: the first one apparently in Madrid, always by the printing press of Pedro Madrigal, who, as we have seen before, had a particular interest in the "English question": $A d$ vertencias que dan los Catolicos Ingleses, à los Catolicos de Francia del peligro en que estan de perder la Religion, si admiten à la Corona Principe Herege. Traduzidas de Frances en Castellano por don Felix de Guzman (Dorléans, 1592a). In the letter "al lector", rather little is said about the occasion for the translation. The focus is more put on the difficulties of rendering a text from another language as difficult as French into Spanish. In the epigrafe we are informed that this text concerns events happening in France from 1562 (beginning of the Wars of Religion) to 1585 . This marks the Advertencias at least a bit as old news, which cannot fully satisfy the general European enchantment for the Cosas de Francia. In the dedication the author said a little more, while studying French, he started reading several books "y entre otros, me vino a las manos uno que han compuesto algunos Catolicos Franceses debaxo de nombre de Ingleses, contra el Principe de Bearne: y por parecerme agudo e ingenioso, y muy proprio para conocer los particullares el estado de las cosas de Francia, y el origen de la tormenta que nuestra religion en ella padece, tome trabajo de traduzirle...". 9

The other translation of Dorléans published in 1592 is Advertencias que los Catolicos de Inglaterra escrivieron a los Catolicos de Francia, tocantes a las presents reboluciones, y cerco de Paris. Por Antonio Herrera, criado de su Majestad, en Zaragoza por Lorenzo Robles, 1592 (Dorléans, 1592b). This text, published at the end of 1592, is different from the one translated by Felix de Guzman, but not just only for a matter of "traduttore traditore", but rather for an editorial choice that renders the book, in the end a gathering of different texts, a volume more sympathetic to the last news coming from France. The dedication here too said little about the reasons of publishing Dorléans six years after its original publication. Antonio Herrera in his letter to don Cristoval de Mora Comendador Major de Alcantara, del consejo de Estado y Guerra de su Majestad, Sumilier de Corps del Principe nuestro señor, Veedor de la hazienda de la Corona de Portugal, did not say much more then de Guzman.

Herrera explains that it was quite some time that he had had this book concerning the advice of an English Catholic to the French ones; that time had passed by and many terrible things had happened, and one fault can be found, as the original author said, (Dorléans is never named) in the custom of according the Huguenots so many edicts of Pacification when they would deserve nothing else than the force, as an experience older than 30 years has shown in England where the Catholics accepted an heretical queen. Herrera acknowledges that the "Advertencias" are now old news, but still their example can be useful to show the danger of a heretical king. To explain what happened in the following years from the original French edition, Herrera includes the translation of other letters and texts: a Carta entitulada açote para los politicos hereges, y traydores de Francia, que se han juntado con el herege Principe de Bearne ${ }^{10}$, "a donde se muestran como estavan las cosas de Francia, luego que murio Enrique III. Y declara el derecho que tenía a la Corona el cardinal de Bourbon, que a la sazon vivia (aunque preso)". ${ }^{11}$ A letter of a Venetian to the Signoria ${ }^{12}$ follows, in which the divisions among the French Princes and their intention to inherit to the crown are explained, as well as that of others like the duke of Savoy, the duke of Lorraine, the duke of Ferrara, and Philip II. He denies Navarre, being a heretic, any right to the throne, and hopes the Signoria will unite with the French Catholics. The next text is a Letter of the Legate Caetani to the Cardinal Montalto ${ }^{13}$ on the events of the siege of Paris and its liberation; the letter is dated $31^{\text {st }}$ August 1590. A short Declaration of the prince of Bearn of the $11^{\text {th }}$ August 1590, is annexed to the letter of Caetani.

The collection continues with a letter of Iusepe Esteban, Obispo de Vesta y Dean de Valencia, to the bishops and clergymen of France. ${ }^{14}$ The eighth text is an Exemplos de los diversos generos de muertes con que han martirizado en Francia, los sequaces del perverso Calvino, y los Ugonotes. ${ }^{15}$ The final piece of the collection of texts, is a letter from Paris dated $7^{\text {th }}$ September 1590, thus after the liberation of the city, that explains what happened during the siege, in particular the "hunger" that was tormenting the Parisians, and the subsequent events of the war that occurred once the Spanish soldiers freed the Capital of France. ${ }^{16}$ In conclusion, Herrera de Tordesillas has made a little effort beside the lengthy translation of the nine texts to put together some congruous pieces of the jigsaw: the introduction seems to have been written too quickly, he is unable to give a clear resume of the different texts he is supposed to have been translating. At times, he confuses one with the other or just forgets to quote. The general impression is the idea that the work is just an "instant book", put together, with a title about the English, and a story concerning the news (that is old, as the book ends with the events of $7^{\text {th }}$ September 1590 and only became available to the public in late 1592) of the French situation, that is not deeply studied. Even the text on the problem of the succession is not one of the best written by the jurists of both parties from 1584 to 1589 .

These two Spanish editions of Dorléans' Advertissement des Catholiques anglois... are an example of the translation into Spanish of French works at the end of the $16^{\text {th }}$ century. Gutierrez in his short catalogue of the translation of French books for the $16^{\text {th }}$ and $17^{\text {th }}$ century, only counts 10 titles (without counting the reeditions) for the period going from 1565 to 1593 (Gutierrez, 1982: 262$265)$. According to the author, being rarities, but also "minor" literary works, on one side these books were to have a larger diffusion, more prestigious and less limited to humanistic circles. On the other side these two translations alongside the works of Pedro Cornejo, Herrera, the vari- 
ous editions of books concerning the Revolt of the Low Countries under Philip II, the later translations of Pierre Matthieu (Matthieu 1625 and 1627), show an interest for the recent history of France, the War of the League, and in particular the Spanish engagement with the French Catholics in the "affaires de Frances". Thus, for the $17^{\text {th }}$ century, the translations of Dorléans have to be examined in a broader historiographical context that concerns the study of recent Spanish and European history that involves the analysis of the wars fought by Philip II in their different theatres, England, The Low Countries, and France. In a general sense, Dorléans' work is a mirror of the reasons of the Catholic League, lengthy evoked in the text, and the fight of the European Catholics, helped by the Spanish monarchy, against heresy, and the changes or subversion of state and religion.

For the readers of the 1590's, Dorléans, alongside the work of Cornejo on the siege of Paris, represent an image that shows the French political and religious situation, its wars, and massacres in its cruel and gruesome reality. An image of the war next door, of what it might become, or is becoming, and the destiny and tragic fate that is expecting the besieged Catholics. Still, edited in the end of 1592, this image looks like some old news. Dorléans wrote his book in 1586: the book, that uses the English example to show what will be the future of France under a heretic ruler, is not about England, its reformation, nor its Catholics, in the end: as mentioned before the Advertissement is a lengthy history of the recent years of the French religious wars, with an heartfelt defence of the League and of the Guise. But the book is old matter even for the readers of 1592 . Written when the succession of Navarra as French King was a possible danger, when the League and Henri III were allied against the Huguenots, the book is a warning against what will be the future of France. Reality, and historical facts, went far beyond the fears of Dorléans. In 1587, an invasion of protestant mercenary, the revolt of Paris in 1588, the killing of the brothers Guise by the king of France at the end of that year, the alliance of this latter with Henri de Navarre, the assassination by a monk of Henri III while he was besieging Paris in 1589, the "succession" of the protestant heir as Henri IV, the battle of Ivry in 1590, the siege of Paris and its over 30.000 deaths, the involvement of the Spanish tercios led by Farnese to free the capital, are events that bypassed Dorléans previsions. At the same time, there are circumstances so important that a 1592 reader could not have missed them. In fact, at the end of that year, the news from France would have been the second Spanish expedition to assist the besieged city of Rouen, the calling for the Estates General for the election of a Catholic King, the discussions for a truce between the fighting parties, even the death of Farnese in December 1592, rather than a book relating events of 1586 . As we have seen, even the polemical use of the English Catholics had generated a sequel of books, pamphlets and answers to make the text of 1586, an ancient polemic, bypassed by writings, and mostly historical developments. Herrera truly tries to modernize his work, associating Dorléans' text with the history of the siege of Paris. But there again, French current affairs, were leading to different issues, solutions, and problematics.

\section{ENGLISH CATHOLICS MATTER}

Richard L. Kagan has noted that "... a lo largo de los años 90 del siglo XVI Herrera escribía una serie de obras dedicadas a los asuntos contemporáneos en Inglaterra y Francia, adoptando en cada una un punto de vista que lo coinvirtiera en el portavoz oficial de la monarquía filipina (see Herrera 1590; Herrera 1598; Kagan, 2004: 41). ${ }^{17}$ Asi, defendía no solo la causa católica sino defendía los derechos del rey Felipe de intervenir en la política de aquellos países. Por lo tanto, no es sorprendente, que al momento que, en 1596, se produjo una plaza del cronista del rey -es este caso, la de Cronista Mayor de las Indias-, el rey eligió Herrera para el cargo a pesar del hecho que nunca había visitado las Indias ni escrito ni una sola palabra de su historia" (Kagan, 2004: 42). ${ }^{18}$

According to Kagan, Antonio de Herrera, used the translation of Dorléans to pose himself as an accomplished historian able to narrate and interpret contemporary events, and this skill helped him obtain the position of Cronista Mayor. This observation made by Kagan apparently confirms the idea that the Advertencias que los Catolicos de Inglaterra escrivieron a los Catolicos de Francia, was nothing more than an "instant book" made and assembled quickly to fulfil a demand. Now the question lies in what was this demand? Did Herrera publish the book to answer the Spanish readers" "thirst" for recent historical facts, or was it something else?

If the instant book hypothesis was true, which reasons motivated for Felix de Guzman, Doctor arcediano y Canonigo de la Catedral de Sevilla, Capellano mayor de su capilla real? Guzman, unlike Herrera, was published by Pedro Madrigal (Delgado Casado, 1996, I: 410-412), ${ }^{19}$ who appears very active in the years from the end of the 1580 's with at least 8 titles concerning "English matters". The Pedro Madrigal's printing machine also produced the Relación de un sacerdote Ingles, escrita a Flandes à un cavallero de su tierra, desterrado por ser Catolico: en la qual le da cuenta de la venida de su Magestad a Valladolid, y al Colegio de los Ingleses, y lo que allí se hizo en su recebimiento. Traduzida de Ingles en Castellano, por Tomas Eclesal, caballero Ingles, en Madrid, (Anonymous, $1592 \mathrm{~b}$ ). The text was for a long time suspected to be the work of Robert Persons. 1592 proved an important date for the English Catholic community resident in Spain: Persons who was sponsored by the King Philip II, and helped by the father provincial of the Company of Jesus Bartolomé Pérez succeeded in renting a first house in Sevilla. From this moment on, those places will be devoted to the maintenance of a community of secular English priests. The father superior would be elected by the chaplains, the consul, and the two oldest members of the community of Catholic merchants in Seville for a three-year periods. Cardinal Allen was nominated Patron, and he himself nominated Persons as Visitor. The new Sevillian 
College in the following years knew some changes of location to be finally fixed in 1595 in the Calle de las armas (Murphy, 2012: 27; Loomie, 1972; Fernández Rojas, 2013: 31-49). Once this important acquisition concluded, Person could go back to Valladolid, where on 2nd August 1592 the Saint Alban English College received a visit of King Philip II and of his heir to the throne.

It has been recently stated that "...royal visits and processions concerning the English College can be interpreted as acts of propaganda performed by the monarchs and their entourage to show support for the English Catholic cause", and, in the same way, the seminarists could use these events for their own propagandistic purposes (Cano Echevarria, Saez Hidalgo, Redworth, Hutchings, 2008: 35 ). Obviously, the trip made by the court to Valladolid had a political purpose. This purpose was well understood by the members of the English College, and a first pamphlet was published in English on the subject: A relation of the King of Spaines, (Anonymous, 1592a; Cock, 1879). ${ }^{20}$ The relation published anonymously was followed by a Spanish translation, as it was common for the English Catholic community in Spain. The author of the text has long been identified as Robert Persons, although a recent study suggests that it could be Joseph Creswell, author of a considerable number of pamphlets in both languages connected with the English College (Cano Echevarria, Saez Hidalgo, Redworth, Hutchings, 2008: 36-37).

The text printed in English or in Spanish also had a polemical purpose: it was meant as an answer to the October 1591 English Royal Proclamation against "seminarie priests and Jesuits", identifying Rome and Spain as the centres of the exiles' conspiracy (Elizabeth I, 1591; Hughes, 1969, III: 88). ${ }^{21}$ Clearly identified as one of the various polemic answers of the English Catholics to the proclamation of 1591, this text has interested historians ever since (Houliston, 2001; Houliston, 2007: 67-68; Cano Echevarria, Saez Hidalgo, Redworth, Hutchings, 2008).

The history of the edition of Dorléans' texts in Spanish in 1592 must be understood not only in terms of their polemical use against Henri of Navarre, proclaimed as King of France by his supporters after the killing of Henri III in 1589, who was still struggling with the League and Spain in order to obtain his crown three years later, but also as an effort of the English Catholic refugees and their network of alliances in Spain to present their tragic situation to the public opinion. The Spanish editions of Dorléans' work were issued as a new English College was founded in the Spanish Kingdom, and just after a royal visit to that of Saint Alban.

Interestingly, both authors may have been connected to the English refugees or royal propaganda: Herrera, $c r i$ ado de su Majestad, might have, as Kagan has suggested, decided to push his future candidatures by releasing a book on France, the object Philip II's strategical plans in 1592. In this way, remembering the tragic destiny of the Englishmen exiled for their religion, Herrera was serving the propaganda and the diplomacy of the king, aimed to secure the religion, and eventually to conquer the crown of France. The edition of Dorléans' work with the addi- tion of eight texts concerning recent events in France, can be, if not a proof, a suggestion aimed to explain why suddenly, years later its first publication in Paris, the allegations of the avocat général de la Ligue, became an important focus of the Spanish printed edition of 1592.

Guzman, Doctor arcediano y Canonigo de la Catedral de Sevilla, Capellano mayor de su capilla real, might have been motivated by similar ideas. The establishment of a new College in Guzmán's city of Seville could have influenced his edition of a text concerning the suffering of the English Catholics. It may also have facilitated his contact with advocates of the English refugees, whose cause he took to heart. Interestingly, as an editor, Guzmán chosen Pedro Madrigal, who had been, as we have seen, very active publishing texts concerning England.

Is it clear that by the use of the press at the end of the sixteenth century, news of events were traveling fast, and they certainly had a public who was interested in buying and reading "los casos" of France or of the Low Countries, where the state was at stake but also religion. The internalisation of the news exchange, which we have seen with Dorléans, but also, with the English College's duallanguage propaganda, the edition of Cornejo in several languages and reedition of his works, had become a way for creating political polemic as well as an interesting economic exchange. There emerged a simple matter of offer and demand: the publication of texts concerning foreign political matters required interested readers, and it seems that their interest was quite significant, as the books were often edited, translated, and re-edited.

In what concerns the two translations of the Catholique anglois, both placed the pamphlet of Loys Dorléans, a polemical text for the French Catholic League, in an international scheme, thus making it useful for the English Catholic community in Spain in the years 1591-1592. Becoming in this way part of a much broader European scenario in which the cause of the English Catholics was known, the text created empathy, was studied and used to show other followers of the old faith the various dangers of heresy, or of an heretical sovereign.

\section{NOTES}

1 Years later his commitment with Henry IV hadn't faded away even after the assassination of the first Bourbon King.

2 The memoirist Pierre de L'Estoile commenting the work wrote that the opening sonnet of the book was enough to send his author to the gibbet: "Ce beau livre, intitulé Le catholique Anglois, et imprimé à Paris en cest an 1586 (où le seul sonnet, mis au commencement dudit livre, est suffisant pour envoier son auteur au gibet, comme coupable et criminel du crime de lèzeMajesté), couroit à Paris, s'y voioit et lisoit avec grande ardeur et recommandation de ceux de la Ligue, pour estre extrêmement injurieux et séditieux contre le Roy de Navarre et tous ceux de son parti, de sa religion et de sa Maison; estant, au reste, bien fait pour une mesdisance, une mauvaise cause aiant rencontré un bon avocat, qui estoit Loïs d'Orléans, advocat au Parlement de Paris; mais peu sage et advisé d'emploier sa rhétorique et son esprit à dénigrer de la maison et sang de France, et au bout faire imprimer son sot livre, pour acquérir bruict d'estre un veau". Sonnet: "France, t'ébahis tu si la Fureur de dieu/Sans cesse te poursuit \& t'ulcere \& te mine/Si la guerre \& 
la peste, \& la pasle famine/Comme un feu devorant te consomme en tout lieu. L'horrible impiété qui dessus ton adveu/ Avecq impunité en ta terre chemine/Le crime d'endurer Iesabel ta voisine/Plonger au sang Chrestien, te sestruit peu à peu. Tu es confederee à la mort qui te suit,/ L'heresie avecq' toy paillarde iour \& nuict,/Tu es la Babilon mere de toute ordure. Ton lis s'en va mourir l'en peux tu garentir? /Il put au nez de Dieu comme une fleur impur/ Il 1'a mis sous le pied pour plus ne le sentir." (L'Estoile, 1875).

3 That same year of 1586 other pamphlets, both reeditions of 1582 texts concerning the English Catholics, were edited in Paris: Epistre de la persecution meue en Angleterre (Anonymous, 1586), a reedition of a 1582 text and the Historia ecclesiastica de martyris fratrum ordini divi Francisci (Bourchier, 1586).

4 «La France... a receu nos pauvres freres en leur affliction ». (Dorléans, 1586)

5 « Ce que nous declarons expressement pour l'experience que nous avons des heretiques, qui à l'exemple de ce grand calomniateur dot ils sont issus, cherchent tous moiens possibles de calomnier les Catholiques envers les Princes : \& par telles calomnies ont fait enterrer Morguant l'un de nos freres Anglois \& Catholique, en la Bastille de Paris ». Thomas Morgan (15461609), a confidant and a spy for Mary Queen of Scots, exiled to France, was involved in the Parry plot. Implicated in this conspiracy by the confession of Thomas Parry, the English asked for his extradition, but Henri III preferred to have him imprisoned at the Bastille. Where he will stay till 1590, but this not prevented Morgan to be part of the Babington plot to assassinate Elizabeth I.

6 The book was edited also this year in Valencia by Pedro Patricio Mey, in Zaragoza, by Pedro Puig and the widow of Juan Escarrilla and in Antwerp, by Plantin.

7 This text had been previously published in Paris in Spanish and in French by Cornejo (1590a and 1590b). The French edition was published in Lyon par J. Pillehotte, Troyes par J. Moreau, in Brussels by Velpius, and in Douai by J. Bogart. Pedro Cornejo was a Carmelite originally from Salamanca, who moved to the Spanish Low countries in 1567 with the duke of Alba, till 1577 when he travelled to Italy (Genoa and Turin), to come back in 1579. Cornejo was known for his historical works concerning the revolt of the Low Countries, published in Lyon (Cornejo, 1577), and later in Turin (Cornejo, 1579); another version was also published in Paris (Cornejo, 1580). His works were also translated in French in Lyon in 1579, and in Italian in Brescia in 1582

8 This text contains also the Discurso y breve relación de las cosa acontecidas en el cerco de la famosa villa de Paris.... On the siege of Paris of 1590 (Cornejo, 1590a).

9 "a don Francisco de Tejada", without pagination, dated Rome, 29 December 1590, signed Don Felix de Guzman.

10 Fol. 104r-137v ; This work is a translation of Le Fouet des héréticques, politiques et traistres de la France associez du feu (sic) roy de Navarre, published in Lyon by Loys Tantillon in 1590 .

11 Ibid. "Epistola dedicatoria", without pagination. This last part concerns also the following letter Carta de un gentilhombre Frances à otro amigo suyo sobre las reboluciones de Francia, fol. $138 \mathrm{r}-443 \mathrm{r}$

12 Carta de un ciudano Veneciano a los señores Senadores de aquella Republica, por las reboluciones de Francia, fol. 143v$152 \mathrm{v}$.

13 Carta del Illustrissimo Cardenal Gaetano Legado apostolico en Francia, al Illustrissimo y Reverendissimo Cardenal de Montalto sobre el cerco de Paris, fols. 153r-159r

14 A los muy amados hermanos Obispos y sacerdotes: $y$ à todos los demas Católicos del Reyno de Francia. D. Iusepe Estevan, Obispo de Vesta, y Dean de Valencia, fol.160v-194v.

15 Fols. 195r-199v. A gruesome list of the crimes committed on Catholics in general, women but especially members of the Clergy, martyrized by the Huguenots since the beginning of the French Wars of Religion.
16 Carta de Paris con particular cuenta de lo sucedido en el cerco, y lo demás hasta lo 7 de septiembre 1590 imbiada a Gabriel de Cayas secretario de estado de su Magestad, y de Italia, fols. 200r-211v.

17 Previously Kagan wrote also: "A sus muchos merito se asomaba su traducción del inglés [sic] de un polémico tratado que aseguraba que el catolicismo en Francia peligraba a menos que Felipe interviniera militarmente para impedir el acceso de un protestante como Enrique de Navarra al trono Francés". Kagan refers to Herrera's work published in Zaragoza in 1592.

18 Kagan follows transcribing: "De otro lado, la consulta que recomendó Herrera para este cargo describió sus credenciales en la manera siguiente: Tradujo la ystoria de Persia y compuso la de Escocia y tradujo lo q escribieron los catholicos ingleses a los franceses el açote de los politicos y el cerco de Paris, la Razon de estado; compuso la ystoria de Portugal y tiene escripta otra general de 27 años de su tiempo que se está examinando por orden del Consejo de Castilla y se entiende que a acabado de describir los tumultos de Francia desde el año de 1585 hasta fin de 1594 provando q V M d se movió a ayudar a los católicos solo por el zelo de la fe". Archivo General de las Indias: Indiferente General, legajo 743, documento 209, consulta de 12 febrero 1595 .

19 Pedro Madrigal was a printer active in Madrid during the years 1586-1594. Before he was probably in Salamanca, according to a document found by Perez Pastor. Established in calle de Atocha in Madrid untill 1594, when we have the last prints of him and his widow Maria Rodriguez Rivalde. At his death his printing house will be continued by his successors.

20 For the propaganda printed by the English Catholic exiles in Antwerp, see the catalogue of an exhibition Antwerp, dissident Typographical Centre (Nave, 1994).

21 "A multitude of dissolute young men, who have partly for lack of living, partly for crimes committed, become fugitives, rebels and traitors, and for whom there are in Rome and Spain and other places certain receptacles made to live in and there to be instructed in school points of sedition and from thence to be secretly and by stealth conveyed into our dominions".

\section{REFERENCES}

Anonymous (1586) Epistre de la persecution meue en Angleterre contre l'Eglise chrestienne catholique et apostolique, et fidèles membres d'icelle, où sont declarez les tourmens très cruels et martyres admirables que les fidèles chrestiens Anglois y souffrent pour leur foy et Religion. Thomas Brunen, Paris.

Anonymous (1592a) A relation of the King of Spaines receiving in Valladolid, and in the Inglish College of the same towne, in August last part of this year. Antwerp.

Anonymous (1592b) Relacion de un sacerdote Ingles, escrita a Flandes, a un caballero de su tierra, desterrado por ser Catolico: en la qual le da cuanta de la venida de si Magestad a Valladolid, y al Colegio de los Ingleses, y loque alli se hizo en su recebimiento. Traduzida de Ingles en castellano por Tomas Eclesal caballero Ingles (E. de la Comp de Iesus). Pedro Madrigal, Madrid.

Arblaster, Paul (2004) Antwerp \& the World. Richard Verstegan and the international culture of Catholic Reformation. Leuven U.P., Leuven.

Barnavi, Elie; Descimon, Robert (1985) La sainte Ligue le juge et la potence. L'assassinat du Président Brisson (15 novembre 1591). Hachette, Paris.

Bourbon, Charles de (1585) Declaration des causes qui ont meu monseigneur le Cardinal de Bourbon, \& les Pairs, Princes, Prelats, Seigneurs, Villes, \& les Communautez Catholiques de ce Royaume, de s'opposer par armes à ceux qui veulent subvertir la religion. [n.e], [n.p].

Bourchier, Thomas (1586) Historia ecclesiastica de martyris fratrum ordini divi Francisci... qui partim in anglia sub Henrico octavo rege, partim in Belgio sub principe Auriaco, partim et in Hybernia tempore leizabethae reginae idque ab anno 1536 
usque ad hunc nostrum presente annum 1582 passi sunt. Guillaume Bichon, Paris.

Cano Echevarria, Berta; Saez Hidalgo, Ana; Redworth, Glyn Hutchings, Mark (2008) "Comfort without offence? The performance and Transmission of exile Literature at the English College, Valladolid, 1592-1600". Renaissance and reformation/ Renaissance et Réforme, 31 (1): 31-67.

Cock, Hendrick (1879) Jornada de Tarazona hecha por Felipe II en 1592 pasando por Segovia: Valladolid, Palencia, Burgos, Lo groño, Pamplona y Tuleda, 1598, edited by Fatio, Manuel; Rodríguez Villa, Antonio and Tello, Alfredo. Madrid.

Cornejo, Pedro (1577) Sumario de las Guerra civiles y causas de la rebellion de Flandes. [n.e], Lyon.

Cornejo, Pedro (1579) Origen de la civil dissension de Flandes. [n.e], Turin.

Cornejo, Pedro (1580) Historia de las civiles guerras de Flandes, recopilada, enmendada y añadida en esta ultima edicion hasta la fin del año ochenta. [n.e], Paris.

Cornejo, Pedro (1590a) Discurso y breve relación de las cosas acontecidas en el cerco de la famosa villa de Paris, y su defensa por el duque de Nemours contra Henrique de Borbon intitulado rey de Navarra y Francia, embiada al serenissimo senor el príncipe de Ascoli. Didier Millot, Paris.

Cornejo, Pedro (1590b) Bref discours et véritable des choses plus notables arrivées au siège mémorable de la renommée ville de Paris, et défence d'icelle par monsiegneur le duc de Nemours, contre le roy de Navarre, par Pierre Cornejo. Didier Millot, Paris.

Cornejo, Pedro (1591a) Compendio y breve relación de la Liga y confederación Francesa: con las cosas en aquel Reyno acontecidas desde el año de ochenta y cinco hasta el presente de noventa, en la cual ultra de la historia se tocan las mas notables cosas q en la Francia se hallan. Vulpius, Brussels.

Cornejo, Pedro (1591b) Discurso y breve relación de las cosas acontecidas en el cerco de la famosa Villa de Paris, y su defensa por el Duque de Nemours, contra Henrique de Borbon, intitulado Rey de Navarra y Francia. Vulpius, Brussels.

Cornejo, Pedro (1592) Compendio y breve relación de la Liga y Confederación Francesa: con las cosas en aquel reyno acontecidas, desde el año de ochenta y cinco hasta el de noventa. Pedro Madrigal, Madrid.

Delgado Casado, Juan (1996) Diccionario de impresores Españoles siglos XV-XVII. Arco Libros, vol. I, Madrid.

Descimon, Robert (1983) Oui étaient les Seize? Mythes et réalités de la Ligue Parisienne (1585-1594). Mémoires publiés par la Fédération des sociétés historiques et archéologiques de Paris et de l'Ile-de-France, Tome 34, Paris.

de L'Estoile, Pierre (1875) Mémoires-Journaux 1574-1611. Vol. 2 Tallandier, Paris.

de L'Estoile, Pierre (1948) Journal pour le Règne d'Henri IV. Gallimard, Paris.

Dorléans, Loys (1572) Imitations de quelques chans de l'Arioste, par diuers poetes françois. L. Breyer, Paris.

Dorléans, Loys (1586) A[d]vertissement, des catholiques anglois aux François [sic] catholiques, du danger où ils sont de perdre leur religion, \& d'expérimenter, comme en Angleterre, la cruauté des ministres, s'ils reçoivent à la couronne un roy qui soit hérétique. L. Breyer, Paris.

Dorléans, Loys (1587a) Advertissement, des catholiques anglois aux Francois catholiques, du danger où ils sont de perdre leur religion, \& d'experimenter, comme en Angleterre, la cruauté des ministres, s'ils reçoivent à la couronne un roy qui soit heretique. En ceste derniere edition augmenté... Approuvé par les docteurs de Louvains. [n.e], [n.p].

Dorléans, Loys (1587b) Replique pour le catholique anglois contre le catholique associé des huguenots. L. Breyer, Paris.

Dorléans, Loys (1590) Premier et second advertisements des catholiques anglois aux François catholiques et à la noblesse qui suit à present le roy de Navarre. Guillaume Bichon, Paris.

Dorléans, Loys (1592a) Advertencias que dan los catolicos, traduzidas de Frances en castellano por don Felix de Guzman. Pedro Madrigal, Madrid.
Dorléans, Loys (1592b) Advertencias que los Católicos de Inglaterra escriuieron a los Católicos de Francia, tocantes a las presentes reboluciones, y cerco de Paris / traduzido de lengua Francesa en Castellana por Antonio de Herrera. Lorenzo de Robles, Zaragoza

Dorléans, Loys (1604) Remerciement au Roy. Chaudière, Paris.

Dorléans, Loys (1607) Les Ouvertures de Parlemens. par Loys d'Orléans, ausquelles sont adjousteees cinq Remonstrnaces autrefois faictes en iceluy. G. des Rues, Paris.

Dorléans, Loys (1612) La plante humaine sur le trespas du roy Henry le Grand où il se traicte du rapport des hommes avec les plantes qui vivent \& meurent de mesme façon :et où se réfute ce qu'a escrit Turquet contre la régence de la Royne et le Parlement, en son livre de la Monarchie Aristodemocratique. A la Royne Mere du Roy Louys XIII, F. Huby, Paris.

Dorléans, Loys (1622) Novae cogitationes in libros annalium C. Cornelii Taciti qui extant. Ad christianiss. Regem Francorum \& Navarrorum Ludovicum XIII. Auctore Ludovico Dorléans Parisiensi. Thomae Blasii, Paris.

Dorléans, Loys (1631) Quatrains moraux pour l'instruction de la jeunesse. F. Targa, Paris.

Duplessis-Mornay, Philippe de (1587) Lettre d'un gentilhomme Catholique François contenant breve response aux calomnies d'un prétendu Anglois. Antoine Chuppin, Zürich.

Elizabeth I (1591) A declaration of great troubles pretended against the realm by a number of seminary priests and Jesuits sent and very secretly dispersed into the same to work great treason under a false pretence of religion with a provision very necessary for the remedy thereof. [n.e.], London.

Fernández Rojas, Matilde (2013) "La compañía de Jesús en Sevilla: el colegio inglés de San Gregorio Magno". Ucoarte. Revista de teoría e historia del Arte, 2: 31-49.

Fumaroli, Marc (1994) L'âge de l'éloquence. Rhétorique et « res literaria » de la Renaissance au seuil de l'époque classique. Albin Michel, Paris.

Gibbons, Katy (2011) English Catholic Exiles in Late SixteenthCentury Paris. Boydell and Brewer, Marthelsham.

Gould, Robert Ch. (1975) The life and political writings of Louis Dorléans, publicist of the French Catholic League. Dissertation (Ph.D.), Bryn Mawr College.

Grê Ponce, Dennis (2014) "Representar el imperio: moral e historia en las narrativas del socorro de Paris de 1590". In Martinez Alcalde, Maria; Ruiz Ibañes, José Javier Felipe II y Almazarrón: la construcción local de un imperio global, vol. 2, Sostener, gobernar y pensar la frontera. Universidad de Murcia, Murcia: 463-475.

Gutierrez, Asensio (1982) La France et les Français dans la littérature espagnole. Un aspect de la xénophobie en Espagne (15981665). Atelier Nationale, Lille.

Herrera, Antonio (1589) Historia de lo sucedido en Escocia, é Inglaterra, en quarenta y quatros años, que biuio Maria Estuarda, reyna de Escocia. Pedro Madrigal, Madrid.

Herrera, Antonio (1590) Historia de lo sucedido En Escocia e Inglaterra en quarenta y quatro años q vivio' Maria Estuardo, Reyna de escocia. [n.e], Lisboa.

Herrera, Antonio (1598), Historia de los sucesos de Francia desde el año 1585, que comenzo' la Liga Catolica, hasta el fin del año 1594. Lorenço de Ayala, Madrid.

Houliston, Victor (2001) "The Lord Treasurer and the Jesuit: Robert Person's Satirical Responsio to the 1591 Proclamation". Sixteenth Century Journal, 32 (2): 383-401.

Houliston, Victor (2007) Catholic resistance in Elizabethan England: Robert Person's Jesuit Polemic, 1580-1610. Ashgate, A1dershot.

Hughes, Paul (editor) (1969) Tudor Royal Proclamations. Vol. 3. Yale University Press, New-Haven, London.

Kagan, Richad L. (2004) "La historia y la crónica de las Indias durante el siglo XVII: Antonio de Herrera y Tordesillas". El imperio sublevado. Monarquía y Naciones en España e Hispanoamérica, edited by Minguez, Victor and Chust, Manuel. Consejo superior de Investigaciones científicas, Madrid: 37-56.

Lestringant, Frank (editor) (1995) Théâtre des cruautéz des herectiques de nostre temps, s.1. 1587. Chandeigne, Paris. 
Loomie, J.A. (1972) "Thomas James, the English Consul of Sanlucar, 1566-c.1613". Recusant History, 11: 165-179.

Manrique Figueroa, Cesar (2012) "Los impresores Bruselenses y su producción dirigida al mercado Hispano, siglo XVI-XVII. El caso de la imprenta del Aguila de Oro de Rutger Velpius, Hubert Anthoine-Velpius y la imprenta de los Mommaert". Erebea, Revista de Humanidades y Ciencias Sociales, $\mathrm{n}^{\circ}$ 2: 205206.

Matthieu, Pierre (1625) Historia de la muerte de Henrico el Grande, quarto rey de Francia de este nombre. Diego Flamenco.

Matthieu, Pierre (1627) Historia de la Guerra de Flandes. Patricio Mey, Valencia.

Murphy, Martin (2012) Ingleses de Sevilla. Universidad de Sevilla, Sevilla.

Nave, Francine de (1994) Antwerp, dissident Typographical Centre: The Role of Antwerp printers in the Religious Conflicts in England (1 $6^{\text {th }}$ Century). Plantin-Moretus Museum-Snoeck-Ducaju $\&$ Zoon, catalogue of an exhibition, Antwerp.

Pallier, Denis (1975) Recherches sur l'imprimerie à Paris pendant la Ligue (1585-1594). Droz, Genève.
Penzi, Marco (2003) "Una città sotto assedio: Parigi nel 1590 o L'histoire tragique et véritable du siège de Paris". Descrivere per raccontare, edited by Siciliani, Erina. Pensa, Lecce: 31-53.

Penzi, Marco (2015) "Les Rouges, les Noirs et les larmes d'un Roi: Autour de l'enregistrement de l'Edit de Nemours dans l'historiographie et l'histoire". Revue du XVIIe siècle n²66: 121-139.

Persons, Robert (1590) Relación de algunos martirios, que de nuevo han hecho los herejes en Inglaterra, y de otras cosas tocantes a nuestra santa y Catolica Religion. Traduzida de Ingles en Castellano, por el Padre Roberto Personio, de la Compañia de Iesus, dirigida a la señora Infanta de Castilla, doña Isabel Clara Eugenia. Pedro Madrigal, Madrid.

Poncet, Olivier (1998) Pomponne de Bellièvre (1529-1607). Un Homme d'état au temps des Guerres de Religion. Ecole des chartes, Paris.

Rivadeneira, Pedro (1588) Historia ecclesiatica del Scisma del reyno de Inglaterra. Pedro Madrigal, Madrid.

Rodriguez Perez, Y. (2003) De Nederlanden in Spaanse historische en literaire tekste. Vanvilt, Nijmegen. 